\title{
Poesía suelta
}

\section{Insuperable Odds}

\section{María Fernanda García Jiménez}

I

n mournful numbers

I shall say,

That 200 million people today

Have had their freedom taken

And their dreams blown away.

What is real anymore?

What is life to those

150 million girls and women

Who will be raped by one more?

Only hope can take us farther

Maybe someone could speak up louder?

Because our destined end or way

Might not have a tomorrow

And only a today.

300 million children

To the grave march

With empty stomachs

And nothing more than

$\$ 1.25$.

Don't follow the crowd

And think on your own

Except when war's at hand

Don't ask, don't judge

Just step on the battle zone.
With God o'erhead,

There seems to be no future.

Let others bury the dead.

Acting in the present

Doesn't matter to those without bread.

What should I leave footprints for?

If there won't be any water or food for all? $12 \%$ of the population uses

The $85 \%$ of the available water reserve. At this pace, there is nothing sublime, It is only a matter of time.

How can I be of any comfort, How can I be someone's path lead?

When out there I see

73 million illiterate women

Who can only beg and plead?

Learn to labor, my child

For tomorrow it'll be a new day, While you run around all wild

Waiting to get through another pay day. 


\title{
Como agua
}

\author{
Galia Ospina Villalba
}
T Tha noche soñé que escribía un poema que contenía al universo entero. Procuré memorizar sus versos y llamé con urgencia a la tinta y al papel.

$\mathrm{Al}$ despertar

las letras se escaparon como arena entre mis dedos.
Desde entonces

busco las palabras que una vez escuché entre el asombro

y la herida del alba.

\section{Voces líquidas (fragmentos)}

\author{
Luis H. Gómez Ordóñez
}

\author{
(...) No te vendas \\ que no te canalicen, \\ que no te entuben, \\ que no te encajen ni te compriman, \\ que no te hagan tabletas, \\ que no te metan en una botella, \\ cuidado! (...) \\ Pablo Neruda, Oda al aire
}

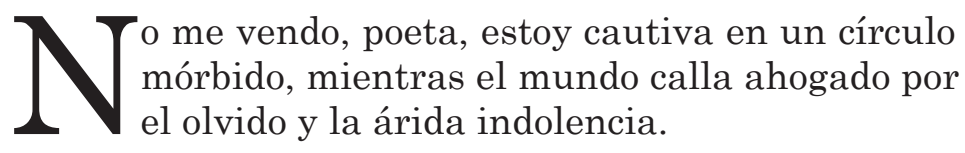

No me canalizan, no me entuban, no me encajan, solo secuentran cauces, ponen mordaza a las veras, encalustran la lluvia y a pesar de ello no me extirpan como itinerario de vida.

No me comprimen, ni me hacen tabletas, ni me embotellan, lo que atrapan es volumen, lo que contienen las botellas y tabletas son fórmulas, quintas esencias, imágenes de manantial en fragmentos. 


\section{Retratos}

\section{Retrato de un avión que se pierde entre unas nubes}

$\Lambda$ l vuelo, la patria se esconde entre el aire, dejan un hueco,

las versiones de lo inconsumable.

Nos lanza al vacío con la ración necesaria para conquistar lo prohibido: hacia donde vayamos nos mirará desde su ojo supuesto.

La nostalgia queda repartida entre nubes, que a donde fuesen que miraran la lluvia nuevamente encarnará el pesaje.

Una frase cocinará la razón: volver al lecho matermo, como una llave que ha de custodiar un tesoro.

De ahora en adelante en cualquier matiz de azul por donde este avión distribuya vida nacerá mi país en otra burbuja.
AleXander ANChía Vindas

\section{Retrato de una estrella}

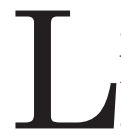
as estrellas no mienten, hablan sobre verdades a medias al fragmentarse de boca en boca, mientras otros deciden estrechar sus valores.

Hacen la bóveda celeste un pasadizo, por donde corre cuanta incertidumbre quepa en una noche.

$\mathrm{Al}$ sorprendernos un tintineo, irrumpe en nuestro itinerario la risa de un santo o la queja de un nido. Hacen un nudo de nuestro entendimiento y se desata una avalancha poética a lo largo de las [constelaciones.

Vienen en hileras de dos, de tres y hasta de millones, para que la suerte quede repartida en el eco de los sueños.

Mientras se pueda perseguir una estrella habrá espacio ilimitado para el amor. 
